\title{
ANALISIS KEMAMPUAN BERPIKIR KREATIF MATEMATIS SISWA SD DALAM MENYELESAIKAN OPEN-ENDED PROBLEM
}

\author{
Dini Ramadhani ${ }^{1}$, Nuryanis ${ }^{2)}$ \\ 1,2 Program Studi Pendidikan Guru Sekolah Dasar \\ FKIP Universitas Samudra Langsa \\ Idhanicurly.dc@gmail.com
}

\begin{tabular}{ll}
\hline $\begin{array}{l}\text { Informasi artikel } \\
\text { Sejarah artikel }\end{array}$ \\
$\begin{array}{l}\text { Diterima } \\
\text { Revisi }\end{array}$ & $:$ I 16 \\
Dipublikasikan & $: 28 / \mathrm{I} 2 / 2107$ \\
Kata kunci: & \\
analisis, \\
berpikir, \\
kreatif matematis \\
open-ended \\
problem
\end{tabular}

\begin{abstract}
ABSTRAK
Kemampuan berpikir kreatif matematis penting dilatih sejak siswa berada di tingkat Sekolah Dasar. Siswa dilatih menyelesaikan open-ended problem agar berkembang pemikiran kreatif matematisnya. Penelitian ini bertujuan memperoleh gambaran tingkat kemampuan berpikir kreatif matematis siswa SD. Sampel penelitian adalah siswa kelas IV SD di Kecamatan Langsa Lama sebanyak 48 orang yang mewakili siswa yang memiliki katagori kemampuan tinggi, sedang, dan rendah. Metode penelitian ini adalah penelitian kualitatif. Instrumen yang digunakan yaitu tes, observasi, dan wawancara. Teknik analisis data dengan cara mereduksi data, menyajikan data, dan menarik kesimpulan serta menggunakan teknik triangulasi data agar memperoleh keabsahan. Hasil penelitian menunjukkan dari I6 siswa pada katagori tinggi, IO orang berada pada level TBKM level 3 (kreatif) dan 6 orang berada pada TBKM level 2 (cukup kreatif). Pada siswa kategori sedang yang berjumlah I6 siswa, terdapat 6 orang berada pada TBKM level 3 (kreatif) dan sebanyak I0 orang berada pada TBKM level 2 (cukup kreatif). Pada siswa katagori kurang dengan jumlah siswa sebanyak 16 orang, sebanyak 2 orang berada pada TBKM level 3 (kreatif), 7 orang berada pada TBKM level 2 (cukup kreatif), dan sebanyak 7 orang berada pada TBKM level I (kurang kreatif).
\end{abstract}

Key word:

analysis,

thinking,

creative mathematical

open-ended

problem

\section{ABSTRACT}

The ability of mathematical creative thinking is important to be trained since the students are at elementary school level. Students are trained to solve open-ended problems in order to develop their mathematical creative thinking. This study aims to obtain a picture of the level of ability to think creatively mathematically in elementary students. The sample of the research is the fourth grader of elementary school in sub-district Langsa Lama as many as 48 people representing students who have high ability category, medium, and low. This research method is qualitative research. The instruments used are test, observation, and interview. Data are analyzed by reducing data, presenting data, and drawing conclusions and using data triangulation techniques in order to obtain validity. The results showed that from I6 students in high category, I0 people were at level 3 (creative) level of TBKM and 6 were on level 2 TBKM (creative enough). In the medium category students who numbered 16 students, there are 6 people are on level 3 TBKM (creative) and as many as IO people are on level 2 TBKM (creative enough) In the category less students with the number of students as much as I6 people, as many as 2 people are on level 3 TBKM (creative), 7 people are on TBKM level 2 (creative enough), and as many as 7 people are at TBKM level I (less creative) 


\section{Pendahuluan}

Pelajaran matematika dalam pelaksanaan pendidikan diberikan kepada semua jenjang pendidikan dimulai dari sekolah dasar (SD) sampai perguruan tinggi. Tujuan dari diberikannya mata pelajaran matematika adalah untuk membekali siswa dengan kemampuan berpikir logis, analitis, sistematis, kritis, dan kreatif, serta kemampuan bekerja sama (Depdiknas, 2006). Pelajaran matematika berkaitan dengan penataan cara berpikir, terutama dalam pembentukan kemampuan menganalisis, membuat sintesis, melakukan evaluasi hingga kemampuan memecahkan masalah.

Siswa kreatif dalam berpikir untuk memecahkan masalah merupakan salah tujuan yang harus dicapai dari mata pelajaran matematika. Berpikir kreatif merupakan pemikiran yang bersifat keaslian dan reflektif dan menghasilkan suatu produk yang komplek dalam permasalahan matematika. Berpikir tersebut melibatkan sintesis ide-ide, membangun ide-ide baru dan menentukan efektivitasnya. Selain itu, berpikir kreatif juga berkaitan dengan kemampuan untuk membuat keputusan dan menghasilkan produk yang baru. Krulik (1999) yang mendefinisikan berpikir kreatif sebagai pemikiran yang original dan menghasilkan suatu hasil yang komplek, yang meliputi merumuskan ide-ide, menghasilkan ide-ide baru, dan menentukan keefektifannya. Sriraman (2004) mengatakan kreativitas sebagai kemampuan untuk menghasilkan karya baru atau asli, tentang kreativitas matematis sebagai proses yang berakibat tidak biasa dan berwawasan solusi untuk masalah tertentu, terlepas dari levelnya kompleksitas. Pengertian ini menunjukkan bahwa berpikir kreatif merupakan suatu proses yang digunakan untuk mendatangkan atau memunculkan suatu ide baru yang bermanfaat yang sebelumnya ide-ide tersebut belum pernah ada.

Sriraman dan Liljedahl (dalam, Aizikovitsh 20I4) mendefenisikan kreativitas matematika dalam konteks sekolah sebagai tingkat proses yang menghasilkan solusi kebaruan yang dapat diberikan pada permasalahan dan atau menjadikan pendekatan lama menjadi baru. Chamberlain and Moon (2005) menunjukkan bahwa siswa kreatif berbakat memiliki kemampuan yang tidak biasa untuk menghasilkan sesuatu yang baru dan solusi berguna untuk masalah simulasi atau nyata, menggunakan model matematika. Lebih jauh Chiu (2009) menghubungkan kreatifitas matematika siwa dengan kemampuan menyelesaikan masalah rutin dan non rutin dan bahkan untuk mendekati masalah terstruktur.

Silver (1997) mengatakan perkembangan kreativitas dalam pemecahan masalah dapat dilihat dari kefasihan fleksibilitas dan kebaruan (novelty). Kefasihan dikembangkan dengan menghasilkan banyak gagasan matematika, banyak jawaban atas masalah matematika, dan mengeksplorasi situasi matematika. Fleksibilitas artinya dapat menghasilkan solusi matematis baru paling tidak satu solusi diberikan. Kebaruan merupakan pengembangan dengan banyak solusi dari masalah matematika dan menghasilkan sesuatu yang baru.

Penilaian kemampuan berpikir kreatif dalam pelajaran matematika (berpikir kreatif matematis) menurut Silver (dalam Siswono, 2007) dilakukan dengan menggunakan The Torance Tests of Creative Thinking (TTCT). Tiga komponen kunci yang dinilai dalam menggunakan TTCT adalah kefasihan (fluency), fleksibilitas dan kebaruan (novelty). Kefasihan mengacu pada banyaknya ide-ide yang dibuat dalam merespon sebuah perintah. Fleksibilitas tampak pada perubahan-perubahan pendekatan ketika merespon perintah. Kebaruan merupakan keaslian ide yang dibuat dalam merespon perintah.

Kemudian Siswono (2007) juga mengembangkan level Tingkat berpikir kreratif ini terdiri dari lima tingkatan yaitu tingkat berpikir kreatif 4 (sangat kreatif), tingkat berpikir kreatif 3 (kreatif), tingkat berpikir kreatif 2 (cukup kreatif), tingkat berpikir kreatif I (kurang kreatif), dan tingkat berpikir kreatif 0 (tidak kreatif). 
Tabel I. Tingkat Berpikir Kreatif Matematis (TBKM) dari Siswono

\begin{tabular}{|c|c|}
\hline $\begin{array}{l}\text { Tingkat Berpikir } \\
\text { Kreatif Matematis } \\
\text { (TBKM) }\end{array}$ & Deskripsi \\
\hline $\begin{array}{l}\text { Level } 4 \\
\text { (sangat kreatif) }\end{array}$ & $\begin{array}{l}\text { Siswa mampu menyelesaikan suatu masalah dengan lebih dari satu } \\
\text { alternatif jawaban maupun cara penyelesaian atau membuat masalah } \\
\text { yang berbeda-beda dengan lancar (fasih) dan fleksibel. }\end{array}$ \\
\hline $\begin{array}{l}\text { Level } 3 \\
\text { (Kreatif) }\end{array}$ & $\begin{array}{l}\text { Siswa mampu menunjukkan suatu jawaban yag baru dengan cara } \\
\text { penyelesaian yang berbeda (fleksibel) meskipun tidak fasih atau } \\
\text { membuat berbagai jawaban yang baru meskipun tidak dengan cara yang } \\
\text { berbeda (tidak fleksibel). Selain itu siswa dapat membuat masalah yang } \\
\text { berbeda dengan lancar (fasih) meskipun jawaban masalah tunggal atau } \\
\text { membuat masalah yang baru dengan jawaban divergen }\end{array}$ \\
\hline $\begin{array}{l}\text { Level } 2 \\
\text { (cukup kreatif) }\end{array}$ & $\begin{array}{l}\text { Siswa mampu membuat satu jawaban atau masalah yang berbeda dari } \\
\text { kebiasaan umum meskipun tidak dengan fleksibel atau fasih, atau } \\
\text { mampu menunjukkan berbagai cara penelesaian yang berbeda dengan } \\
\text { fasih meskipun jawaban yang dihasilakan tidak baru. }\end{array}$ \\
\hline $\begin{array}{l}\text { Level I } \\
\text { (kurang kreatif) }\end{array}$ & $\begin{array}{l}\text { Siswa tidak mampu membuat jawaban atau membuat masalah yang } \\
\text { berbeda (baru), meskipun salah satu kondisi berikut dipenuhi, aitu cara } \\
\text { penyelesaian yang dibuat berbeda-beda (fleksibel) atau jawaban/ } \\
\text { masalah yang dibuat beragam (fasih) }\end{array}$ \\
\hline $\begin{array}{l}\text { Level } 0 \\
\text { (tidak kreatif) }\end{array}$ & $\begin{array}{l}\text { Siswa tidak mampu membuat alternatif jawaban maupun cara } \\
\text { penyelesaiany atau membuat masalah yang berbeda dengan lancar } \\
\text { (fasih) dan fleksibel. }\end{array}$ \\
\hline
\end{tabular}

Pengembangan kemampuan ini dalam pembelajaran matematika dilakukan dengan pelaksanaan pembelajaran matematika yang melibatkan aktivitas yang kreatif dan dengan memberikan permasalahan atau soal matematika yang bersifat terbuka (open ended problem) pada siswa. Yee (2002) mendefenisikan "open-ended problems as ill-structuredproblem because the involve missing data or assumptions and they have no fixed procedures that guarantees a correct solution". Permasalahan yang bersifat terbuka, yaitu masalah atau soal yang dalam penyelesaiannya membutuhkan banyak cara atau membutuhkan banyak jawaban yang benar. Dari jawaban atau cara penyelesaian siswa dalam memecahkan masalah atau soal yang bersifat terbuka yang diberikan akan diketahui tingkat pemikiran kreatif siswa. Apakah siswa tersebut sudah kreatif dalam berpikir atau belum.

Menurut Becker \& Epstein (Wijaya, 2012) suatu soal dapat terbuka dalam tiga kemungkinan sebagai berikut.

I. Proses yang terbuka yaitu ketika soal menekankan pada cara dan strategi yang berbeda dalam menemukan solusi yang tepat. Jenis soal semacam ini masih mungkin memiliki satu solusi tunggal.

2. Hasil akhir yang terbuka yaitu ketika soal memiliki jawaban akhir yang berbeda-beda. 
3. Cara untuk mengembangkan yang terbuka, yaitu ketika soal menekankan pada bagaimana siswa dapat mengembangkan soal baru berdasarkan soal awal (initial problem) yang diberikan.

Berdasarkan observasi di beberapa sekolah khususnya SD di Kecamatan Langsa Lama diperoleh data bahwa dalam pembelajaran matematika di SD dilakukan dengan cara pemberitahuan. Pembelajaran dilakukan guru dengan menyampaikan materi pembelajaran dengan menggunakan metode ekspositori yaitu guru mengajar dengan one way communication, memberikan ceramah, menjejali siswa dengan materi secara verbal symbol, sehingga pembelajaran berjalan satu arah, kurang melibatkan dan memberdayakan potensi siswa secara komprehensif. Guru memberikan siswa bacaan, meniru, melihat dan mengamati materi pada buku paket.

Selain itu, soal-soal yang diberikan kepada siswa bersifat tertutup, yaitu soal-soal yang menuntut satu jawaban yang benar. Di samping itu, guru terbiasa memberikan contoh soal dan penyelesaiannya sehingga siswa ketika siswa menyelesaikan permasalahan atau soal, siswa cenderung melakukannya sesuai dengan contoh yang diberikan guru. Ketika diberikan soal yang berbeda dari contoh yang diberikan guru, siswa mempertanyakan bagaimana menyelesaikannya. Terkait dengan hal itu, siswa meminta guru untuk memberikan contoh serupa yang sesuai dengan soal yang diberikan.

Selain melakukan observasi, tim penulis juga melakukan wawancara terhadap guru-guru SD di Kecamatan Langsa Lama. Wawancara dilakukan terhadap tingkat pemikiran kreatif siswa. Berdasarkan hasil wawancara diperoleh data bahwa guru tidak mengetahui hal tersebut. Hal ini disebabkan karena, selama ini kemampuan berpikir kreatif tidak menjadi bagian dari sasaran hasil yang ingin dicapai dalam pembelajaran matematika di SD.

Oleh sebab itu, penelit tertarik untuk melakukan penelitian dalam rangka mengungkap kemampuan berpikir kreatif matematis siswa SD dalam menyelesaikan open-endep problem yang ada di Kecamatan Langsa Lama, khususnya terhadap siswa kelas IV SD. Penelitian ini akan menganalisis kemampuan berpikir kreatif matematis siswa pada katagori tinggi dan melihat sejauh mana tingkat berpikir kreatif matematis siswa tersebut.

\section{Metode Penelitian}

Metode yang digunakan dalam penelitian ini adalah metode kualitatif. Metode kualitatif bertujuan untuk menjelaskan fenomena yang terjadi secara menyeluruh melalui pengumpulan data yang diperoleh. pendekatan kualitatif, peneliti ingin memperoleh data yang mendalam sehingga dapat mengetahui kemampuan berpikir kreatif siswa dalam menyelesaikan open-ended problem. Teknik pengambilan sampel pada penelitian ini dilakukan dengan teknik purposive sampling. Subjek dalam penelitian ini adalah siswa kelas IV SD yang ada di Kecamatan Langsa Lama. Subjek dipilih dengan mengambil perwakilan 2 orang yang memiliki peringkat tinggi, sedang, dan kurang. Penelitian ini menggunakan tiga metode pengumpulan data yaitu tes kemampuan berpikir kreatif matematis berupa open-ended problem, wawancara, dan observasi. Pada penelitian ini teknik analisis data yang digunakan mengadopsi dan mengembangkan oleh Miles dan Hiberman yaitu, reduksi data, menyajikan data, dan menarik kesimpulan. Setelah data dianalisis sampai ditemukan jawaban dari pertanyaan penelitian, selanjutnya dilakukan pengecekan kevalidan atau keabsahan data temuan. Pengecekan keabsahan data ini dilakukan dengan menggunakan teknik triangulasi

\section{Hasil dan Pembahasan}

Berdasarkan analisis kemampuan berpikir kreatif subjek meliputi hasil tes kemampuan berpikir kreatif berupa open-ended problem, observasi, dan hasil wawancara. Hasil tes, observasi dan wawancara akan dijadikan acuan untuk mengelompokkan siswa ke dalam tingkat kemampuan berpikir kreatif matematis. Hasil penelitian menunjukkan dari 48 subjek penelitian I8 orang berada pada level TBKM level 3 (kreatif), 23 orang berada pada TBKM level 2 (cukup kreatif) dan 7 orang berada pada TBKM level I 
(kurang kreatif). Berikut hasil analisis tingkat kemampuan berpikir kreatif matematis siswa berdasarkan tingkat kemampuannya.

Hasil analisis kemampuan berpikir kreatif matematis siswa yang mempunyai tingkat kemampuan tinggi yaitu sebanyak 10 orang (subjek T-3, T-5, T-6, T-9, T-II, T-I2, T-I4, T-I5, dan T-I6) berada pada TBKM level 3 (kreatif) dan sebanyak 6 orang (T-I, T-2, T-4, T-7, T-8, dan T-I0) berada pada TBKM level 2 (cukup kreatif).

Secara umum indikator kefasihan (fluency) telah terpenuhi oleh subjek T-I hingga T-I6. Dimana sebanyak 6 orang (subjek T-6, T-II, T-I2, T-I4, T-I5, dan T-I6) telah mampu mengerjakan soal dengan sangat lancar. Sebanyak 9 orang (subjek T-I, T-2, T-3, T-4, T-5, T-7, T-9, T-I0, dan T-I3) mengerjakan soal dengan lancar. Hanya I orang (subjek T-4) yang mengerjakan soal dengan cukup lancar. Subjek penelitian telah mampu mengerjakan permasalahan dengan fasih dan lancar. Subjek penelitian lancar dalam menyebutkan informasi yang disediakan dalam soal. Sehingga mereka tidak merasa kesulitan untuk mengerjakan soal dan yakin jawabannya benar. Hal ini dikarenakan mereka telah memiliki pengetahuan yang cukup tentang materi operasi pecahan. Jawaban yang diberikan diusakan lebih dari satu jawaban. Subjek penelitian mengerjakan dengan proses yang benar serta penjelasan yang diberikan cukup lengkap.

Pencapaian indikator keluwesan (flexibility) subjek T-I hingga T-I6 berdada pada kategori cukup luwes. Pada indikator keluwesan ini sebanyak 9 orang (subjek T-3, T-4, T-8, T-II, T-I2, T-I4, TI5, dan T-I6) sudah mengerjakan soal dengan luwes. Sebanyak 7 orang (subjek T-I, T-2, T-5, T-6, T-7, dan T-I0) mengerjakan soal dengan kurang luwes. Sebagian subjek penelitian telah mencoba untuk memberikan jawaban dengan lebih satu cara, namun masih banyak yang melakukan kekeliruan dalam proses perhitungannya. Beberapa orang telah menunjukkan hal-hal dipertimbangkan dalam menyelesaikan soal dan konsep yang dimunculkan dalam menyelesaikan soal yang diberikan. Namun, untuk beberapa subjek lain belum mengerti maksud dari permasalahan sehingga hanya mampu menemukan satu cara dalam menyelesaikan masalah.

Pada indikator kebaruan (novelty) subjek penelitian pada katagori tinggi hanya mampu berada pada tingkat cukup baru. Dimana sebanyak 2 orang (subjek T-5, dan T-9) telah mampu mengerjakan soal dengan cara baru. Sebanyak 9 orang (subjek T-3, T-6, T-I0, T-II, T-I2, T-I3, T-I4, T-I5, dan TI6) mengerjakan soal dengan cukup baru. Sebanyak 3 orang (subjek T-I, T-4, dan T-8) yang mengerjakan soal dengan kurang baru. Hanya 2 orang (subjek T-2 dan T-7) yang mengerjakan dengan cara tidak baru. Pada soal dengan indikator kebaruan, subjek penelitian hanya sebagian yang menunjukkan kebaruan. Subjek penelitian hanya terbiasa dengan cara yang mereka yang telah pelajari. Sehingga kurang bisa memberikan ide baru untuk memecahkan soal dengan cara mereka sendiri. Subjek penelitian mengaku jika belum pernah mengerjakan soal seperti yang diberikan. Subjek penelitian terbiasa mengerjakan soal yang hanya mirip dengan contoh soal yang ada dibuku saja. Jika diberikan soal yang sedikit berbeda mereka bingung untuk menyelesaikannya.

Hasil analisis kemampuan berpikir kreatif matematis siswa yang mempunyai tingkat kemampuan sedang yaitu sebanyak 6 orang (subjek S-3, S-7, S-II, S-I2, S-I3, dan S-I5) berada pada TBKM level 3 (kreatif) dan sebanyak 10 orang (S-I, S-2, S-4, S-5, S-6, S-8, S-9, S-I0, S-I4, dan S-I6) berada pada TBKM level 2 (cukup kreatif).

Secara umum indikator kefasihan (fluency) telah terpenuhi oleh subjek S-I hingga S-I6. Dimana sebanyak 5 orang (subjek S-3, S-II, S-I2, S-I5, dan S-I6) telah mampu mengerjakan soal dengan sangat lancar. Sebanyak 7 orang (subjek S-I, S-2, S-4, S-5, S-6, S-7, dan S-8) mengerjakan soal dengan lancar. Sebanyak 4 orang (Subjek S-9, S-I0, S-I3, dam S-I4) yang mengerjakan soal dengan cukup lancar. Subjek penelitian telah mampu mengerjakan permasalahan dengan fasih dan lancar. Subjek penelitian lancar dalam menyebutkan informasi yang disediakan dalam soal. Sehingga mereka tidak merasa kesulitan untuk mengerjakan soal dan yakin jawabannya benar. Hal ini dikarenakan mereka telah memiliki pengetahuan yang cukup tentang materi operasi pecahan. Jawaban yang diberikan 
diusakan lebih dari satu jawaban. Subjek penelitian mengerjakan dengan proses yang benar serta penjelasan yang diberikan cukup lengkap.

Pencapaian indikator keluwesan (flexibility) subjek S-I hingga S-I6 berada pada kategori cukup luwes. Pada indikator keluwesan ini sebanyak 2 orang (subjek S-I3 dan S-I4) sudah mengerjakan soal dengan sangat luwes. Sebanyak 3 orang (subjek S-4, S-I I, dan S-I2) mengerjakan soal dengan luwes. Sebanyak I orang (subjek S-I5) mengerjakan dengan soal dengan cukup luwes. Sebanyak 9 orang (subjek S-I, S2, S-3, S-5, S-6, S-7, S-8, S-9, dan S-I0) mengerjakan soal dengan kurang luwes. Sebanyak I orang (S16) mengerjakan soal dengan tidak luwes. Sebagian kecil subjek penelitian telah mencoba untuk memberikan jawaban dengan lebih satu cara, namun masih banyak yang melakukan kekeliruan dalam proses perhitungannya. Beberapa orang telah menunjukkan hal-hal dipertimbangkan dalam menyelesaikan soal dan konsep yang dimunculkan dalam menyelesaikan soal yang diberikan. Namun, untuk beberapa subjek lain belum mengerti maksud dari permasalahan sehingga hanya mampu menemukan satu cara dalam menyelesaikan masalah.

Pada indikator kebaruan (novelty) subjek penelitian pada katagori sedang hanya mampu berada pada tingkat cukup baru. Dimana sebanyak I orang (subjek S-7) telah mampu mengerjakan soal dengan cara sangat baru. Sebanyak 2 orang (subjek S-I3 dan S-I5) mengerjakan soal dengan baru. Sebanyak 6 orang (subjek S-2, S-5, S-8, S-II, S-I2, dan S-I4) yang mengerjakan soal dengan cukup baru. Sebanyak 5 orang (subjekS-3, S-4, S-9, S-I0, dan S-I6) yang mengerjakan dengan cara kurang baru. Sebanyak 2 orang (subjek S-I dan S-6) yang mengerjakan soal dengan cara tidak baru. Pada soal dengan indikator kebaruan, subjek penelitian hanya sebagian yang menunjukkan kebaruan. Subjek penelitian hanya terbiasa dengan cara yang mereka yang telah pelajari. Sehingga kurang bisa memberikan ide baru untuk memecahkan soal dengan cara mereka sendiri. Subjek penelitian mengaku jika belum pernah mengerjakan soal seperti yang diberikan. Subjek penelitian terbiasa mengerjakan soal yang hanya mirip dengan contoh soal yang ada dibuku saja. Jika diberikan soal yang sedikit berbeda mereka bingung untuk menyelesaikannya.

Hasil analisis kemampuan berpikir kreatif matematis siswa yang mempunyai tingkat kemampuan kurang yaitu sebanyak 2 orang (subjek K-I I dan K-I2) berada pada TBKM level 3 (kreatif). Sebanyak 7 orang (subjek K-I, K-2, K-3, K-I0, K-I3, K-I4, dan KI5) berada pada TBKM level 2 (cukup kreatif). Untuk TBKM level I (kurang kreatif) sebanyak 7 orang (subjek K-4, K-5, K-6, K-7, K-8, K9, dan K-I6).

Secara umum indikator kefasihan (fluency) telah terpenuhi oleh subjek K-I hingga K-I6. Dimana sebanyak 2 orang (subjek K-II dan K-I5) telah mampu mengerjakan soal dengan sangat lancar. Sebanyak I orang (subjek K-I2) mengerjakan soal dengan lancar. Sebanyak 8 orang (Subjek K-I, K-2, K-3, K-4, K-9, K-I0, K-I3 dan K-I4) yang mengerjakan soal dengan cukup lancar. Sebanyak 4 orang (subjek K-5, K-6, K-7 dan K-I6) yang mengerjakan soal dengan kurang lancar. Sebanyak I orang (subjek K-8) mengerjakan soal dengan tidak lancar. Subjek penelitian telah mampu mengerjakan permasalahan dengan cukup fasih dan lancar. Subjek penelitian cukup lancar dalam menyebutkan informasi yang disediakan dalam soal. Sehingga sebahagian mereka tidak merasa kesulitan untuk mengerjakan soal dan yakin jawabannya benar. Hal ini dikarenakan mereka telah memiliki pengetahuan yang cukup tentang materi operasi pecahan. Sebagian subjek pada tingkat kurang ini mencoba memberikan lebih dari satu jawaban. Subjek penelitian mengerjakan dengan proses yang cukup benar serta penjelasan yang diberikan cukup lengkap.

Pencapaian indikator keluwesan (flexibility) subjek K-I hingga K-I6 berada pada kategori kurang luwes. Pada indikator keluwesan ini sebanyak 3 orang (subjek K-II, K-I2 dan K-I4) sudah mengerjakan soal dengan luwes. Sebanyak 8 orang (subjek K-I, K-2, K-3, K-7, K-8, K-IO, K-I3, dan K-I5) mengerjakan soal dengan kurang luwes. Sebanyak 5 orang (subjek K-4, K-5, K-6, K-9, dan K16) mengerjakan dengan soal dengan tidak luwes. Sebagian besar subjek penelitian tidak memberikan jawaban atau memberikan jawaban yang salah. Serta banyak subjek penelitian yang melakukan 
kekeliruan dalam proses perhitungannya. Subjek penelitian tidak menunjukkan hal-hal dipertimbangkan dalam menyelesaikan soal dan konsep yang dimunculkan dalam menyelesaikan soal yang diberikan. Sehingga dapat disimpulkan subjek pada katagori kurang ini kurang mengerti maksud dari permasalahan sehingga hanya mampu menemukan satu cara dalam menyelesaikan masalah bahkan tidak memberikan jawaban.

Pada indikator kebaruan (novelty) subjek penelitian pada katagori kurang hanya mampu berada pada tingkat cukup baru. Dimana sebanyak 4 orang (subjek K-II, K-I2, K-I3, dan K-I4) telah mampu mengerjakan soal dengan cara cukup baru. Sebanyak 6 orang (subjek K-I, K-2, K-3, K-4, K-I0, dan KI5) mengerjakan soal dengan cara kurang baru. Sebanyak 6 orang (subjek K-5, K-6, K-7, K-8, K-9, dan K-I6) yang mengerjakan soal dengan cara tidak baru. Pada soal dengan indikator kebaruan, subjek penelitian hanya sebagian kecil yang menunjukkan kebaruan. Sebagian besar menunjukkan ketidakbaruan mereka dalam menjawab soal. Subjek penelitian hanya terbiasa dengan cara yang mereka yang telah pelajari. Sehingga kurang bisa memberikan ide baru untuk memecahkan soal dengan cara mereka sendiri. Subjek penelitian mengaku jika belum pernah mengerjakan soal seperti yang diberikan. Subjek penelitian terbiasa mengerjakan soal yang hanya mirip dengan contoh soal yang ada dibuku saja. Jika diberikan soal yang sedikit berbeda mereka bingung untuk menyelesaikannya.

\section{Kesimpulan}

Berdasarkan hasil penelitian di atas maka dapat disimpulkan bahwa tingkat kemampuan berpikir kreatif matematis siswa SD dalam menyelesaikan open-ended problem di Kecamatan Langsa Lama yaitu 48 subjek penelitian masih berada di level TBKM level 2 (cukup kreatif). Sebanyak I8 orang berada pada level TBKM level 3 (kreatif), 23 orang berada pada TBKM level 2 (cukup kreatif) dan 7 orang berada pada TBKM level I (kurang kreatif).

Pada siswa berkemampuan tinggi, subjek T-I hingga T-I6 telah memenuhi indikator kefasihan, cukup luwes, dan cukup baru. Oleh karena itu dapat disimpulkan siswa dengan kemampuan tinggi berada pada Tingkat Berpikir Kreatif Matematis Level 3 atau kreatif. Siswa dengan tingkat kemampuan tinggi mampu menyelesaikan masalah dengan fasih dan lancar serta dapat memberikan bergam jawaban yang benar. Selain itu siswa pada tingkat kemampuan tingngi cukup mampu menyelesaikan masalah dengan cara yang berbeda serta cara yang digunakan cukup baru dengan pemikiran sendiri.

Sedanngkan untuk siswa berkemampuan sedang, Subjek S-I hingga S-I6 telah memenuhi indikator kefasihan, cukup luwes, dan cukup baru. Oleh karena itu dapat disimpulkan siswa dengan kemampuan sedang berada pada Tingkat Berpikir Kreatif Matematis Level 2 atau cukup kreatif. Siswa dengan tingkat kemampuan sedang mampu menyelesaikan masalah dengan fasih dan lancar serta dapat memberikan bergam jawaban yang benar. Selain itu siswa pada tingkat kemampuan sedang cukup mampu menyelesaikan masalah dengan cara yang berbeda serta cara yang digunakan cukup baru dengan pemikiran sendiri.

Pada siswa berkemampuan kurang, subjek K-I hingga K-I6 telah cukup memenuhi indikator kefasihan, kurang luwes, dan kurang baru. Oleh karena itu dapat disimpulkan siswa dengan kemampuan kurang berada pada Tingkat Berpikir Kreatif Matematis Level 2 atau cukup kreatif. Siswa dengan tingkat kemampuan kurang mampu menyelesaikan masalah dengan fasih dan lancar serta dapat kurang mampu memberikan beragam jawaban yang benar. Selain itu siswa pada tingkat kemampuan kurang cukup mampu menyelesaikan masalah dengan cara yang berbeda serta cara yang digunakan cukup baru dengan pemikiran sendiri. 


\section{Referensi}

Aizikovitsh 2014. The Extent of Mathematical Creativity and Aesthetics in Solving Problems among Students Attending the Mathematically Talented Youth Program. Creative Education,5, 228-24I. Diakses Dari http://file.scirp.org/pdf/CE_2014031217160229.pdf

Al-Absi, M.. 2013. The Effect of Open-ended Tasks as an assessment tool on Fourth Graders' Mathematics Achievement, and Assessing Students'. Journal of Educational Sciences Vol. 9 No. 3. Hal. 345-35I.

Chamberlain and Moon (2005) Chamberlin, S. A., \& Moon, S. (2005). Model-Eliciting Activities: An Introduction to Gifted Education. Journal of Second- ary Gifted Education, 17, 37-47.

Chiu (2009) Chiu, M.-S. (2009). Approaches to the Teaching of Creative and Non-Creative Mathematical Problems. International Journal of Science and Mathematics Education, 7, 55-79. Diakses dari http://dx.doi.org/I0.1007/sI0763-007-9I12-9

Depdiknas. 2006. Kurikulum Tingkat Satuan Pendidikan. Jakarta : Depdiknas.

Ervynck G. (2002) Mathematical Creativity. In: Tall D. (eds) Advanced Mathematical Thinking. Mathematics Education Library, vol II. Springer, Dordrecht. http://doi.org.ololo.sci-hub.bz/I0.1007/0-30647203-I_3

Krulik, Stephen \& Rudnick, Jesse A. (I999). Innovative Tasks To Improve Critical and Creative Thinking Skills. Dalam Stiff, Lee V. Curcio, Frances R. (eds). Developing Mathematical reasoning in Grades KI2. I999 Year book. h.I38-I45. Reston: The National Council of teachers of Mathematics, Inc.

Leikin, Roza \& Lev, Miriam . (20I2). Mathematical Creativity In Generally Gifted and Mathematically Excelling adolescent: What Makes The Difference? ZDM Mathematic Education, 45, I83-I97. Diakses dari http://sci-hub.bz/I0.1007/sI I858-0I2-0460-8

Huda, C. 20I I. Meningkatkan Kemampuan Berpikir Kreatif Siswa dalam Memecahkan Masalah Matematika dengan Model Pembelajaran Treffinger pada Materi Pokok Keliling dan Luas Persegipanjang. Diakses dari (http:/ /digilib.sunan-ampel.ac.id/gdl.php?mod=browse\&op=read\&id=jiptiain--chotmilhud-9908

Hwang, W. Y., Chen, N.S., Dung, J.J., \& Yang, Y. L. (2007). Multiple Representation Skills and Creativity Effects on Matematical Problem Solving Using a Multimedia Whiteboard System. Educational Technology \& Society, I0, I9I-I92, Diakses dari http://www.ifets.info/journals/I0_2/I7.pdf

Inprasitha, Maitree. 2006. "Open Ended Approach and Teacher Education”. SPRING: Tsukuba Journal of Educational Study in Mathematics. Vol.25

Quality Enhancement Plant. (20I4 ). High-order Skills in Critical and Creative Thinking. NC Stae University, USA. https://northgatech.edu/downloadFile.aspx?query=QEP\%20Final\%20Document.pdf

Schrauth, A, Michelle. (2014). Fostering Mathematical Creativity In The Middle Grades: Pedagogical and Mathematical Practices. (Doctoral Disertasi, Texas State University, 20I4). Diakses dari https://ecommons.txstate.edu/bitstream/handle/I0877/5260/SCHRAUTH-DISSERTATION20I4.pdf?sequence $=\mathrm{I}$ \&isAllowed $=\mathrm{y}$

Silver, E. (1997). Fostering Creativity through Instruction Rich in Mathematical Problem Solving and Problem Posing. ZDM, 3, 75-80. http://dx.doi.org/I0.I007/sI I858-997-0003-x

Siregar, Syofyan. 2013. Metode penelitian kuantitatif; dilengkapi perbandingan perhitungan manual dan SPSS. Edisi pertama. Jakarta: Kencana Prenada Media Group.

Siswono, Tatag Y.E. 2007. Desain Tugas untuk Mengidentifikasi kemampuan berpikir Kreatif Siswa dalam Matematika. Jurusan Matematika FMIPA: Universitas Negeri Surabaya (Online). Terseida: di tatagyes.files.wordpress.com/2007/I0/tatag_jurnal_unej.pdf [25 juni 20I3]

Siswono, Eko, Y,T. (20II). Level of Student's Creative Thinking In Classroom Matematics. Educational Research and 6(7), Review, 548-553. Diakses dari http://www.academicjournals.org/article/articleI379767432_Siswono.pdf 
Sriraman, Bharath. (2004). The Characteristics of Mathematical Creativity. The Mathematics Educator, I4(I), 19-34. Diakses dari http://citeseerx.ist.psu.edu/viewdoc/download?doi=IO.I.I.848.4348\&rep $=$ repI\&type $=$ pdf

Suherman, Erman. (2003). Strategi Pembelajaran Matematika Kontemporer. Bandung:JICA Universitas Pendidikan Indonesia

Yee, F.P. (2002). Using Short Open Ended Question to Promote Thinking and Understanding. In Rogerson (ed). The Mathematics Educations Education into 2Ist Century Project. Proceeding of The International Conference in Matehmatics Education, pp I35 - I4I.

Wijaya, A. (2012). Pendidikan Matematika Realistik: Suatu Alternatif Pendekatan Pembelajaran Matematika. Yogyakarta : Graha Ilmu. 